\title{
Assessment of groundwater potential based on aquifer properties of hard rock terrain in the Chittar-Uppodai watershed, Tamil Nadu, India
}

\author{
T. Jeyavel Raja Kumar • A. Balasubramanian • \\ R. S. Kumar · C. Dushiyanthan · B. Thiruneelakandan • \\ R. Suresh $\cdot$ K. Karthikeyan $\cdot$ D. Davidraju
}

Received: 4 February 2013/Accepted: 20 June 2014/Published online: 15 July 2014

(C) The Author(s) 2014. This article is published with open access at Springerlink.com

\begin{abstract}
Aquifer performance was tested in 24 locations to assess the groundwater potential of the hard rock terrain in the Chittar-Uppodai watershed of the Tambaraparani River basin. Geologically, the area consists of biotite gneiss, charnockite, and quartzite. The aquifer characteristics, such as transmissivity (T), the storage coefficient, specific capacity, optimum yield, and the recovery rate were calculated. The drawdown transmissivity was determined using Jacob's straight-line method, while the recovery transmissivity was determined by the Theis method. The drawdown transmissivity was low in the western areas, particularly at Kadayanallur, and was higher in the other areas. The recovery transmissivity was high in the western area, and, with the exception of Gangaikondan, was low at other locations. The assessment indicates that there is groundwater potential in the western part of the study area because of favorable results for recovery drawdown, aquifer thickness, and specific capacity.
\end{abstract}

Keywords Aquifer characteristics - Pumping test . Transmissivity · Groundwater potential $\cdot$ Chittar-Uppodai

T. J. R. Kumar $(\bowtie) \cdot$ R. S. Kumar · C. Dushiyanthan .

B. Thiruneelakandan $\cdot$ R. Suresh

Department of Earth Sciences, Annamalai University,

Annamalai Nagar 608002, India

e-mail: tjeyavel@rediffmail.com

A. Balasubramanian

University of Mysore, Mysore, India

K. Karthikeyan

Department of Civil Engineering, Annamalai University, Annamalai Nagar 608002, India

D. Davidraju

Government Engineering College, Tirunelveli, India

\section{Introduction}

The world's total water resource is estimated at $1.37 \times 10^{8}$ million ha. Of this, about $97.2 \%$ is salt water, mainly found in the oceans, and only $2.8 \%$ is available as fresh water (Kumar et al. 2005). Groundwater that can be extracted economically using present drilling techniques accounts for about only $0.3 \%\left(41.1 \times 10^{4}\right.$ million ha) of the available freshwater; much of the remaining supply is unavailable as it is situated deeper than $800 \mathrm{~m}$ (Patel 2004). Presently, groundwater is a very important source of freshwater for humans. It fulfills most of the requirements for a wide range of uses, and so demand for groundwater has increased manifold. Given the increased demand, it is necessary to understand the groundwater resources so as to be able to supply present and future generations. More efficient tools are needed for groundwater exploration, so as to meet the increased demand for water supply, but also to protect the water resource. A number of geophysical techniques that were developed to support exploration activities can also be used to assess hydrogeological structures.

In general, geophysical methods, particularly resistivity techniques, provide information about the physical properties of the underground lithology. The field resistivity response of sub-surface strata ultimately helps to determine groundwater potential and hydraulic properties by errorfree interpretation. Nevertheless, a study of aquifer properties will provide more relevant information on the aquifer characteristics of the terrain that controls the groundwater storage and movement. Out of the hydraulic study methods, an in situ test is the most effective way to determine the hydraulic characteristics of water-bearing layers. This test allows hydrogeologists to quantify the groundwater and the hydraulic conductivity, which mainly depend on 
secondary porosity in the hard rock aquifer (Jain 1977). The hydraulic study of the aquifer performance test/ pumping test is normally done in large-diameter wells in hard rock terrain, as they generally have more exposed fractures and fracture planes (Jain 1977; Aravindan et al. 2004; Bala et al. 2011).

Theis (1935) first proposed a method to evaluate aquifer parameters from pumping tests in confined aquifers. The occurrence and movement of groundwater in massive crystalline rocks are mainly controlled by the extent of weathering, fracture characteristics, discontinuities, and permeability. Even in normal precipitation conditions, the infiltration capacity rate normally varies widely over a catchment area in response to a number of closely related influencing factors, such as soil, slope, thickness of the weathered strata, and vegetation (Mahajan 1995). Groundwater demand is increasing gradually every year in the Chittar-Uppodai sub-basin. To provide information on aquifer characteristics needed for groundwater development, pumping tests were carried out in different locations. Parameters of the aquifer such as drawdown and recovery transmissivity, specific capacity, aquifer thickness, and storage coefficient derived from pumping tests were evaluated and described in this paper. This evaluation will provide the necessary hydrogeological information that will help us understand the aquifer potential, so that we can locate the potential groundwater zones for development.

\section{Study area}

A map of the study area is shown in Fig. 1. The Chittar and Uppodai are tributaries of the Tambaraparani River. They are predominantly covered by eight taluks (groups of villages), of which six belong to the Tirunelveli District and two belong to the Tuticorin District, of Tamil Nadu State, Southern India. The River Chittar crosses an area of about $80 \mathrm{~km}$, and joins the Tambaraparani near Sivalaperi Village. The Chittar-Uppodai sub-basin has an area of about $2,310 \mathrm{~km}^{2}$, of which $183 \mathrm{~km}^{2}$ is covered by a forest reserve and includes around 130 village panchayats, either fully or in part. It lies between $77^{\circ} 10^{\prime} \mathrm{E}-77^{\circ} 55^{\prime} \mathrm{E}$ and $8^{\circ} 50^{\prime} \mathrm{N}-9^{\circ} 10^{\prime} \mathrm{N}$, according to the Survey of India Toposheets $58 \mathrm{G} / 8,12,13,16$ and $58 \mathrm{H} / 1,5,9$. Physiographically,

Fig. 1 Map of the study area

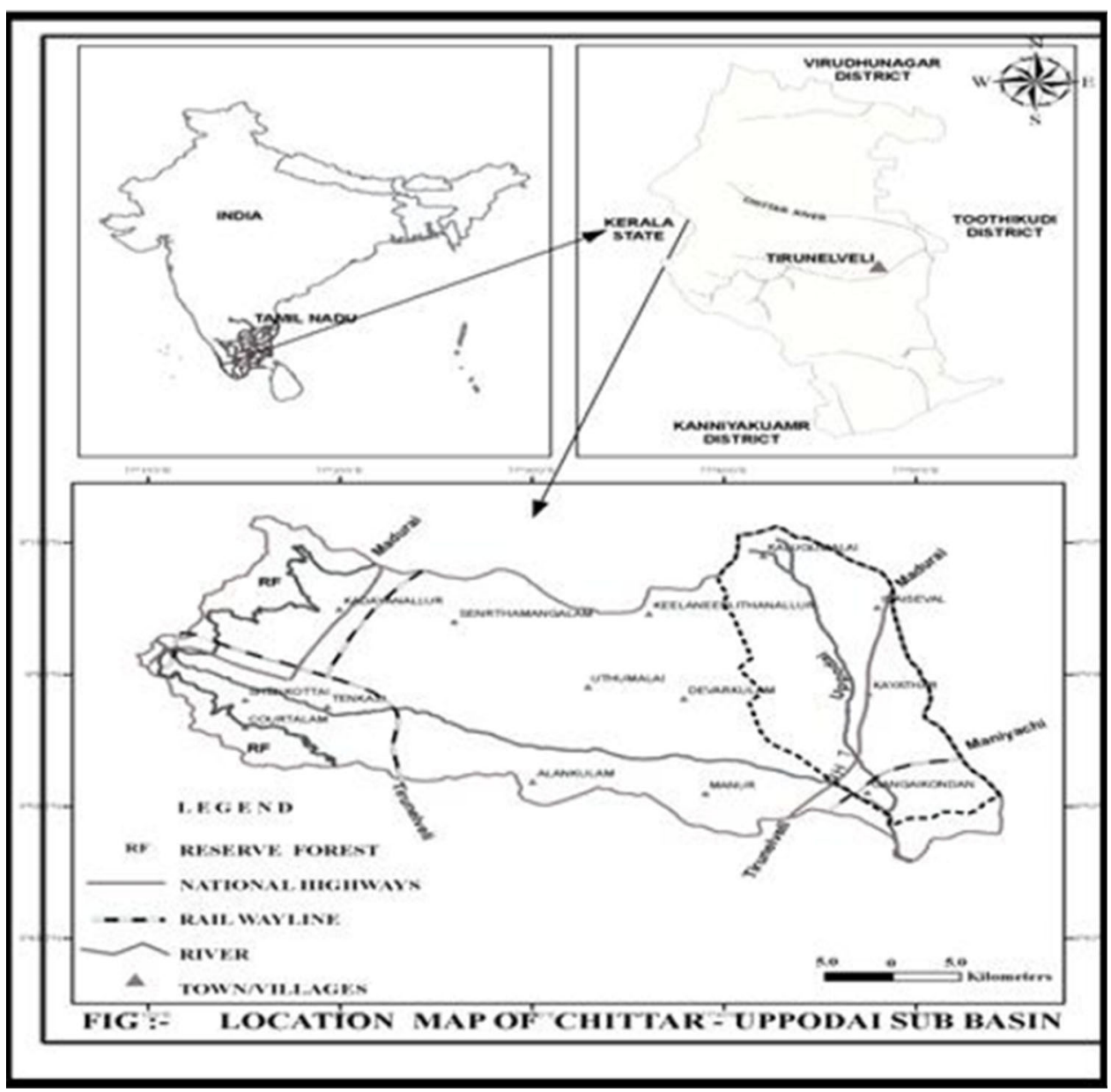


the eastern part of the sub-basin is mainly flat, with a minimum elevation ranging from 60 to $80 \mathrm{~m}$ above mean sea level, and the slope angles range from $<1$ to 1 . In the western part, the landscape is dominated with undulating plains, and the slope angles range from 1 to 3 . The Western Ghats mark the western boundary of the sub-basin. The plains in the basin have been classified as semi-arid (Ram Mohan 1984).

The geological map of the study area is shown in Fig. 2. The study area is chiefly constrained by crystalline rocks of Archean age consisting of gneisses, charnockites, granites, and basic and acidic intrusive igneous structures (Balasubramanian 1986). The lineaments generally trend in WNW-ESE and NW-SE directions. A few minor lineaments in the hilly and secondary structures are visible in the litho units of the district (Abdulla and Paranthaman 1983; Abdulla 1981). Black cotton soils, red soils, laterites, and alluvium soils are the main soil groups in the study area (Balasubramanian 1986). The plain region is mostly covered by black cotton soil, which is locally known as Karisal. In this basin, water occurs mainly in the water table of the weathered crystalline complex terrains and in hydrogeologically unconfined to semi-confined aquifers. Secondary porosity and lineaments will provide the most potential for groundwater development. The major geomorphological units are pediments and buried pediments; flood plains, bazada, and structural hills are also present in the study area, as shown in Fig. 3.

\section{Materials and methods}

The pumping test method is usually preferred for groundwater development and management on a regional scale, and for determining aquifer hydraulic characteristics (Singhal and Gupta 1999). In the present study, pumping tests were carried out at 24 open wells in the study area, all

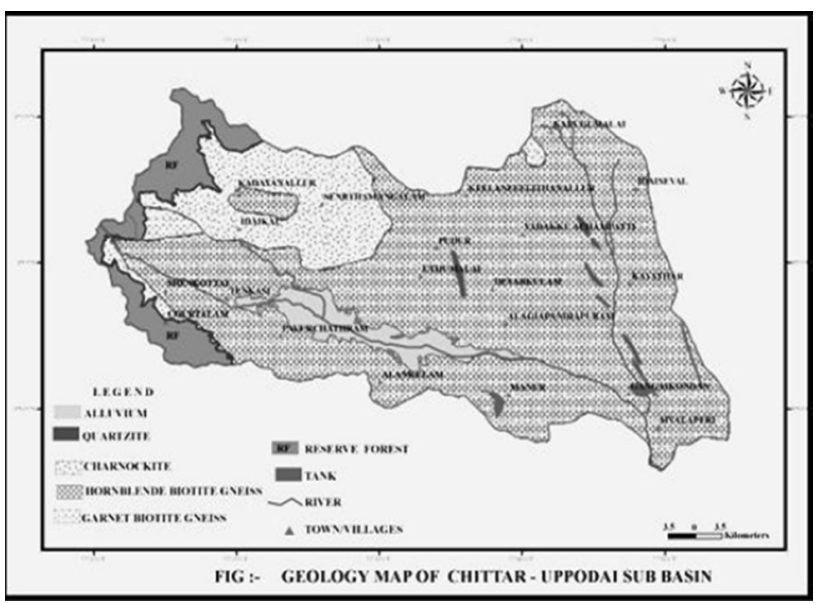

Fig. 2 Geology map

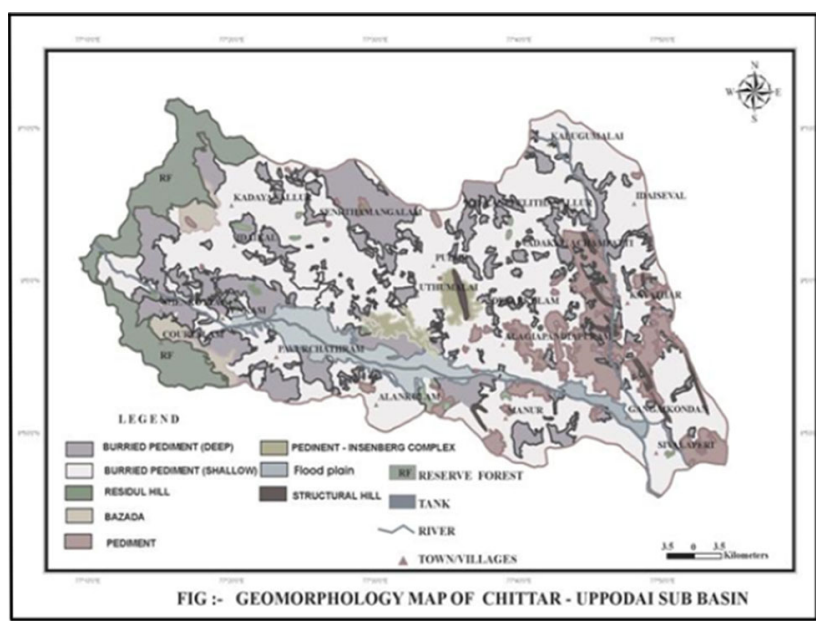

Fig. 3 Geomorphology map

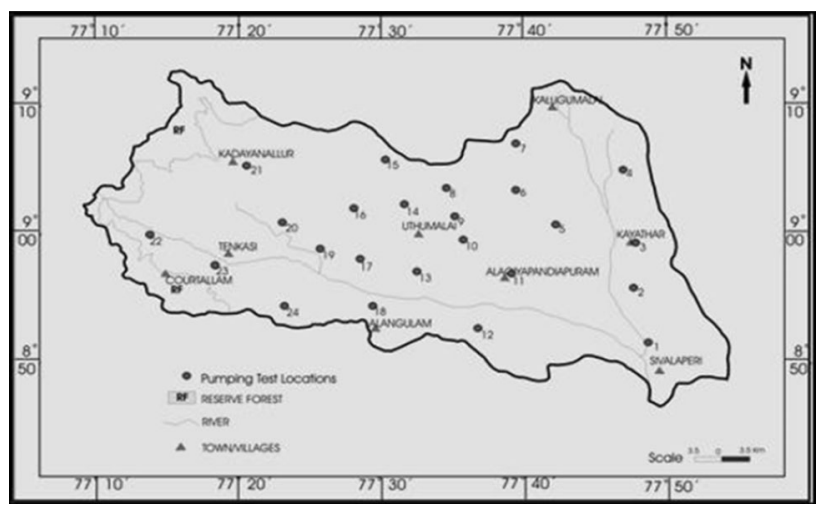

Fig. 4 Pumping test locations

of which are used to irrigate farm lands (Fig. 4). All the pumped wells are open wells and, like most wells in the study area, rectangular in shape. From the ground level, all the open wells penetrated partially into, or just reached, the basement rocks. Before starting to pump water from the wells, the water level from the ground level was measured manually using an ordinary measuring tape. The discharge rate during pumping was determined from the time taken to fill the tank. The study was conducted during the summer season, and the water level in most of the wells was low, so the water discharge time was not long. In this study, drawdown measurement time varied from 30 to $150 \mathrm{~min}$, and the recovery measured was $240 \mathrm{~min}$.

In the last two or three decades, many computer methods have been proposed for analyzing data from pumping tests. Balasubramanian (1986) reviewed the availability and suitability of numerous digital techniques for analyzing pumping test data of wells. Numerical methods can be helpful where there is large variability in flow patterns and porous media properties (Prodanoff et al. 2006). Important aquifer parameters, like transmissivity $(T)$, the storage 
coefficient, specific capacity, optimum yield, and time required for full recovery, have been calculated using BASIC programming software. In this study, a freely available program called aquifer performance analysis (APE) was used (Balasubramanian and Sastri 1989). The software helps to determine the specific capacity using methods derived by Slitcher (1906), Walton (1970), Limaye (1973), Narasimhan (1965) and Singhal (1984). The storage coefficient, optimum yield, recovery time, and aquifer thickness were calculated from the drawdown and recovery measurement data, well dimensions, water level, and discharge. Transmissivity can help us understand the groundwater potential, secondary porosity, and hydrogeological conditions of an area for groundwater development. Besides, to understand the aquifer disturbance and deviation in the observed drawdown values, the APE software provides automated values for the least-squares fit of the well yield and transmissivity, storage coefficient and average drawdown error by sensitivity analysis (McElwee 1980a, b).

\section{Results and discussion}

Results

Transmissivity and hydraulic conductivity are among the most important hydrogeological data needed for managing groundwater resources. Transmissivity describes the general ability of an aquifer to transmit water over the entire saturated thickness, while hydraulic conductivity measures this ability by unit area. The hydrogeological conditions of the area have been evaluated based on the pump test results. Information about drawdown and recovery transmissivity in the present study area aquifer is presented in Table 1 .

\section{Storage coefficient}

The specific capacity of a well is a measure of both the effectiveness of a well and also the aquifer characteristics of transmissivity and storativity. It is defined as the ratio of pumping rate and the drawdown (Summers 1972). The

Table 1 Aquifer parameters evaluated in dug wells

\begin{tabular}{|c|c|c|c|c|c|c|}
\hline \multirow{2}{*}{$\begin{array}{l}\text { Well } \\
\text { no. }\end{array}$} & \multirow[t]{2}{*}{ Location } & \multicolumn{3}{|l|}{ Transmissivity $\left(\mathrm{m}^{2} / \mathrm{d}\right)$} & \multicolumn{2}{|l|}{ Storage coefficient } \\
\hline & & $\begin{array}{l}\text { Jacob's straight-line } \\
\text { method }(\mathrm{msq} / \mathrm{d})\end{array}$ & $\begin{array}{l}\text { Sensitivity analysis } \\
(\mathrm{msq} / \mathrm{d})\end{array}$ & $\begin{array}{l}\text { Theis recovery method } \\
(\mathrm{msq} / \mathrm{d})\end{array}$ & $\begin{array}{l}\text { Jacob's straight-line } \\
\text { method }\end{array}$ & $\begin{array}{l}\text { Sensitivity } \\
\text { analysis }\end{array}$ \\
\hline 1 & Gangaikondan & 167.4367 & 162.7513 & 121.4954 & 0.00009 & 0.10157 \\
\hline 2 & Rajaputhukudi & 85.50594 & 80.30435 & 35.41079 & 0.00001 & 0.01673 \\
\hline 3 & Kayathar & 99.30902 & 90.77951 & 55.79242 & 0.00001 & 0.01746 \\
\hline 4 & Idaiseval & 43.6525 & 32.95784 & 83.46983 & 0.0004 & 0.01535 \\
\hline 5 & Kalampatti & 48.08246 & 40.06921 & 99.40349 & 0.00163 & 0.01746 \\
\hline 6 & Kokkukulam & 72.43754 & 66.33941 & 41.63445 & 0.00017 & 0.01515 \\
\hline 7 & Kilneelithanallur & 168.7711 & 166.2095 & 29.59557 & 0.00001 & 0.03585 \\
\hline 8 & Kurukkalpatti & 37.33464 & 25.44836 & 92.92116 & 0.00048 & 0.01897 \\
\hline 9 & Devarkulam & 128.407 & 128.0788 & 49.49422 & 0.00003 & 0.017 \\
\hline 10 & Vagaikulam & 56.17762 & 51.1073 & 64.11801 & 0.00005 & 0.00738 \\
\hline 11 & Alagiyapandiapuram & 161.0692 & 158.6998 & 33.95149 & 0.00005 & 0.04306 \\
\hline 12 & Kottaimalai & 40.59711 & 31.0666 & 35.64955 & 0.00542 & 0.0355 \\
\hline 13 & Nachiapuram & 93.66692 & 88.90721 & 65.04877 & 0 & 0.01821 \\
\hline 14 & Kuruvankottai & 108.2369 & 107.5954 & 31.20648 & 0 & 0.02961 \\
\hline 15 & Naduvakurichi & 63.84789 & 53.23615 & 70.03058 & 0.00254 & 0.03309 \\
\hline 16 & Senthamaram & 145.6872 & 142.7961 & 117.4769 & 0 & 0.00722 \\
\hline 17 & Veeranam & 107.7298 & 105.2084 & 54.10275 & 0 & 0.02032 \\
\hline 18 & Alangulam & 70.09821 & 64.17412 & 56.67225 & 0.00001 & 0.01341 \\
\hline 19 & Surandai & 79.05647 & 68.19044 & 42.55618 & 0.00228 & 0.04823 \\
\hline 20 & Keelapavoor & 51.6125 & 38.51236 & 57.06315 & 0.00337 & 0.03191 \\
\hline 21 & Kadayanallur & 33.12493 & 27.81248 & 95.88891 & 0.0021 & 0.01015 \\
\hline 22 & Panpozhi & 42.31416 & 37.02972 & 171.8892 & 0.00142 & 0.04601 \\
\hline 23 & Melagaram & 41.21351 & 32.89842 & 75.74801 & 0.00362 & 0.01794 \\
\hline 24 & Petanathanpatti & 33.98535 & 23.62834 & 81.34942 & 0.00463 & 0.0203 \\
\hline
\end{tabular}


Table 2 Different indices of specific capacity calculated for dug wells

\begin{tabular}{|c|c|c|c|c|c|c|c|c|}
\hline Well no. & Location & $\begin{array}{l}\text { Slichter's } \\
\text { specific } \\
\text { capacity } \\
(1 \mathrm{pm} / \mathrm{mdd} / \mathrm{m})\end{array}$ & $\begin{array}{l}\text { Walton's } \\
\text { specific } \\
\text { capacity index } \\
(\mathrm{lpm} / \mathrm{mdd} / \mathrm{m})\end{array}$ & $\begin{array}{l}\text { Narasimhan's } \\
\text { unit area } \\
\text { capacity } \\
\left(\mathrm{lpm} / \mathrm{mdd} / \mathrm{m}^{2}\right)\end{array}$ & $\begin{array}{l}\text { Singhal's } \\
\text { specific capacity } \\
\text { index } \\
\left(1 \mathrm{pm} / \mathrm{mdd} / \mathrm{m}^{2}\right)\end{array}$ & $\begin{array}{l}\text { Limaye's modified } \\
\text { specific capacity } \\
\text { index } \\
\left(1 \mathrm{pm} / \mathrm{mdd} / \mathrm{m}^{2}\right)\end{array}$ & $\begin{array}{l}\text { Optimum } \\
\text { yield } \\
\left(\mathrm{m}^{3} / \mathrm{d}\right)\end{array}$ & $\begin{array}{l}\text { Saturated } \\
\text { thickness } \\
\text { (m) }\end{array}$ \\
\hline 1 & Gangaikondan & $3,758.8$ & $5,011.79$ & 97.63 & 227.9 & 68.35 & 100 & 0.75 \\
\hline 2 & Rajaputhukudi & 47.59 & 30.7 & 1.59 & 0.698 & 0.485 & 3 & 1.55 \\
\hline 3 & Kayathar & 113.43 & 113.43 & 3.17 & 2.364 & 1.355 & 6.7 & 1.0 \\
\hline 4 & Idaiseval & 84.41 & 33.92 & 1.86 & 0.628 & 0.47 & 22.3 & 2.5 \\
\hline 5 & Kalampatti & 80.7 & 27.83 & 1.92 & 0.535 & 0.419 & 37.8 & 2.9 \\
\hline 6 & Kokkukulam & 80.95 & 50.6 & 2.7 & 1.15 & 0.807 & 8.4 & 1.6 \\
\hline 7 & Kilneelithanallur & 82.91 & 207.27 & 4.15 & 5.76 & 2.411 & 3.1 & 0.4 \\
\hline 8 & Kurukkalpatti & 10.79 & 2.25 & 0.36 & 0.051 & 0.045 & 1.2 & 4.8 \\
\hline 9 & Devarkulam & 36.83 & 17.96 & 1.23 & 0.408 & 0.306 & 0.6 & 2.05 \\
\hline 10 & Vagaikulam & 159.69 & 72.59 & 3.26 & 1.267 & 0.928 & 6.8 & 2.2 \\
\hline 11 & Alagiyapandiapuram & 162.34 & 154.61 & 10.31 & 4.833 & 3.29 & 9.0 & 0.05 \\
\hline 12 & Kottaimalai & 29.27 & 6.36 & 1.46 & 0.177 & 0.158 & 40.7 & 4.6 \\
\hline 13 & Nachiapuram & 77.96 & 77.96 & 2.6 & 1.773 & 1.054 & 2.7 & 1.0 \\
\hline 14 & Kuruvankottai & 42.77 & 23.76 & 2.85 & 0.743 & 0.589 & 1.3 & 1.8 \\
\hline 15 & Naduvakurichi & 222.35 & 49.41 & 7.41 & 1.123 & 0.976 & 139 & 4.5 \\
\hline 16 & Senthamaram & 389.61 & 487.02 & 4.33 & 6.411 & 2.584 & 6.2 & 0.8 \\
\hline 17 & Veeranam & 54 & 72 & 2.16 & 1.801 & 0.982 & 1.0 & 0.75 \\
\hline 18 & Alangulam & 94.79 & 63.19 & 2.71 & 1.317 & 0.886 & 6.4 & 1.5 \\
\hline 19 & Surandai & 73.63 & 12.07 & 3.68 & 0.335 & 0.307 & 72.1 & 6.1 \\
\hline 20 & Keelapavoor & 53.86 & 13.3 & 1.8 & 0.302 & 0.259 & 145.3 & 4.05 \\
\hline 21 & Kadayanallur & 109.06 & 16.91 & 2.24 & 0.302 & 0.266 & 60.3 & 6.45 \\
\hline 22 & Panpozhi & 197.52 & 30.96 & 3.1 & 1.095 & 0.809 & 23.2 & 6.38 \\
\hline 23 & Melagaram & 91.28 & 14.96 & 2.34 & 0.299 & 0.265 & 71.4 & 6.1 \\
\hline 24 & Petanathanpatti & 17.57 & 2.83 & 0.49 & 0.059 & 0.053 & 14.7 & 6.2 \\
\hline
\end{tabular}

specific capacity is not a constant, but varies with pumping time, pumping rate, well construction, boundary conditions in the aquifer, and the influence of nearby pumping wells. In this study, the specific capacity was calculated using the methods developed by Slichter (1906), Walton (1970), Narasimhan (1965), Singhal (1984) and Limaye (1973); calculated values for these methods varied from 10.79 to $3,758.801 \mathrm{pm} / \mathrm{mdd} / \mathrm{m}$ (liter per minute per drawdown per meter), 2.25 to $5,011.791 \mathrm{pm} / \mathrm{mdd} / \mathrm{m}, 0.36$ to $97.631 \mathrm{pm} / \mathrm{mdd} / \mathrm{m}, 0.051$ to $227.91 \mathrm{pm} / \mathrm{mdd} / \mathrm{m}, 0.045$ to $68.351 \mathrm{pm} / \mathrm{mdd} / \mathrm{m}$, respectively. The derived values are presented in Table 2 .

Todd (1980) defined the storage coefficient $(S)$ as the volume of water that an aquifer releases or takes into storage per unit surface area of the aquifer per unit component of the head normal to that surface. In an unconfined aquifer, the storage coefficient corresponds to its specific yield. For unconfined aquifers, this is simply expressed by the product of the volume of the aquifer lying between the water table at the beginning and at the end of a specified period of time and the average specific yield of the formation. The value of storativity for water table aquifers varies from 0.01 to 0.35 , while for confined aquifers, it varies from 0.00001 to 0.001 (Ramakrishnan 1998). Besides, storativity normally varies directly with aquifer thickness, and depends on grain size, shape and distribution of pores, compaction of the stratum, and time of discharge (McQueen 1973). In the study area, results show that the storage coefficient varied from values below the measurable level to 0.005 . Values indicate that storativity in the rock formations is much lower than the normal range of $0.01-0.35$, so the groundwater potential is not good in the study area.

Storativity at Nachiapuram, Kuruvankottai, Senthamaram, and Veeranam was below measurable levels, but was 0.005 at Kottaimalai. The sensitivity analysis gave results ranging from 0.007 to 0.101 ; the lowest value was found at Senthamaram and the highest was found at Gangaikondan.

Transmissivity

Theis (1935) introduced the hydraulic characteristic transmissivity or coefficient of transmissivity in groundwater. 
Transmissivity is defined as the rate at which water of a certain prevailing kinematic viscosity is transmitted through a unit width of the aquifer under a unit hydraulic gradient (Todd 1980). The transmissivity of a soil or rock also depends on a variety of physical factors, including porosity, particle size, and the distribution and arrangement of particles (Rasmussen 1964). In the study area, the drawdown transmissivity varied from 33.12 to $167.43 \mathrm{msq} /$ d. Values were lower at Kadayanallur and Petanathanpatti, and were higher at Alagiyapandiapuram and Gangaikondan. Low values for drawdown indicate the potential aquifer condition, and high values indicate poor aquifer condition. The minimum values for recovery transmissivity calculated using the Theis method were $29.59 \mathrm{msq} / \mathrm{d}$ at Kilneelithanallur, and $31.20 \mathrm{msq} / \mathrm{d}$ at Kuruvankottai; values as high as 121.49 and $171.88 \mathrm{msq} / \mathrm{d}$ were observed at Gangaikondan and Panpozhi. The transmissivity calculated by sensitivity analysis varied from 23.62 to $162.75 \mathrm{msq} / \mathrm{d}$. The lowest value was found at Petanathanpatti, and the highest value was observed at Gangaikondan. The spatial distributions of drawdown and recovery transmissivity in the area are shown in Fig. 5a, b.

\section{Optimum yield and saturated thickness}

Optimum yield is a unique aquifer parameter that can be used to develop a discharge and management plan of groundwater resources. It is closely associated with the sub-surface lithology and other aquifer parameters. It helps to control the water level depletion and maintain equilibrium in the aquifer over a long period. In the study area, the optimum yield varied from 0.6 to $139 \mathrm{~m}^{3} / \mathrm{d}$ (Fig. 6). The yield was lower at Devarkulam, and was high at Naduvakurichi. The low yield may be because of the presence of a thin layer of weathered rock and massive rocks. The high yield at Surandai is because of the presence of weathered, jointed rocks, and its proximity to the Chittar River.

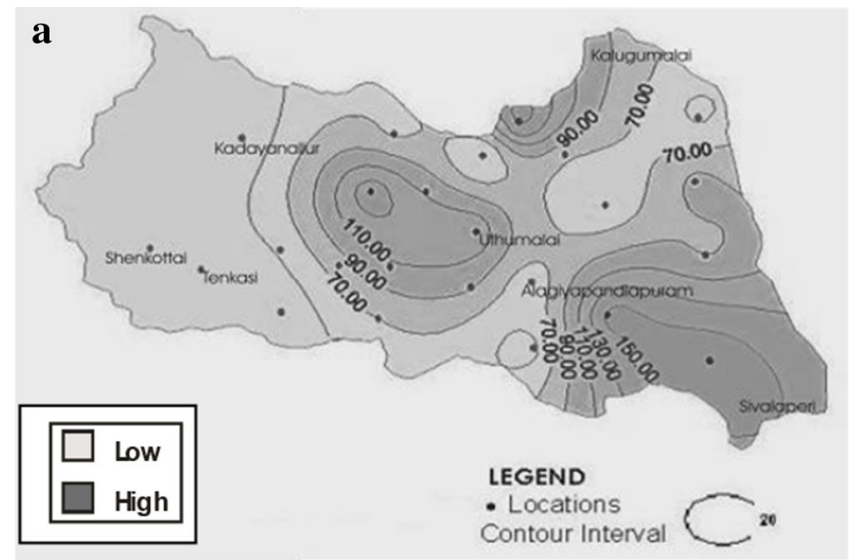

As far as groundwater is concerned, aquifer thickness is closely associated with the transmissivity and storativity of any terrain. The aquifer thickness of the study area varied from 0.04 to $6.45 \mathrm{~m}$ bgl. The aquifer was thickest (thickness $\geq 6 \mathrm{~m}$ ) in the western part of the area at locations such as Keelapavur, Kadayanallur, Panpozhi, and Melagarm, as shown in Fig. 7. The aquifer was least thick $(\leq 1 \mathrm{~m})$ in the middle and eastern parts, and, in particular, at Gangaikondan, Kilneelithanallur, Alagiyapandiapuram, and Veeranam. There may be bazada and deep pediments in the thicker aquifers, while thinner aquifers may have shallow pediments. The recovery time also varied from 1 to $490 \mathrm{~h}$, and was lowest where the aquifer was thickest, particularly in Kadayanallur. Similarly, high recovery transmissivity was observed when the aquifer was thicker, except at Gangaikondan. In Gangaikondan, the aquifer was thinner, but the recovery transmissivity was high.

\section{Discussion}

The study indicates that the drawdown and recovery transmissivity in the study area varied from 33.12 to $168.77 \mathrm{~m}^{2} /$ day, and from 31.20 to $171.88 \mathrm{~m}^{2} /$ day, respectively. The transmissivity values reflect the variability in the thickness and permeability of the aquifer levels. Drawdown was low and the transmissivity recovery was high at Kadayanallur, Panpozhi, Kurukalpatti, and Petanathanpatti. The low drawdown and high recovery may be attributed to the general hydraulic characteristics of the aquifer, for example, the presence of interlinked secondary pores, weathered strata, fractures and influence of lineaments. Similarly, drawdown was high and recovery was low at Alagiyapandiapuram, Kuruvankottai, Devarkulam, Kilneelithanallur, and Rajaputhkudi, and may be a function of the hydraulic characteristics of the fine grained aquifer, including poor connectivity of pores, and a lack of fractures and joints in the sub-surface layers. The low recovery

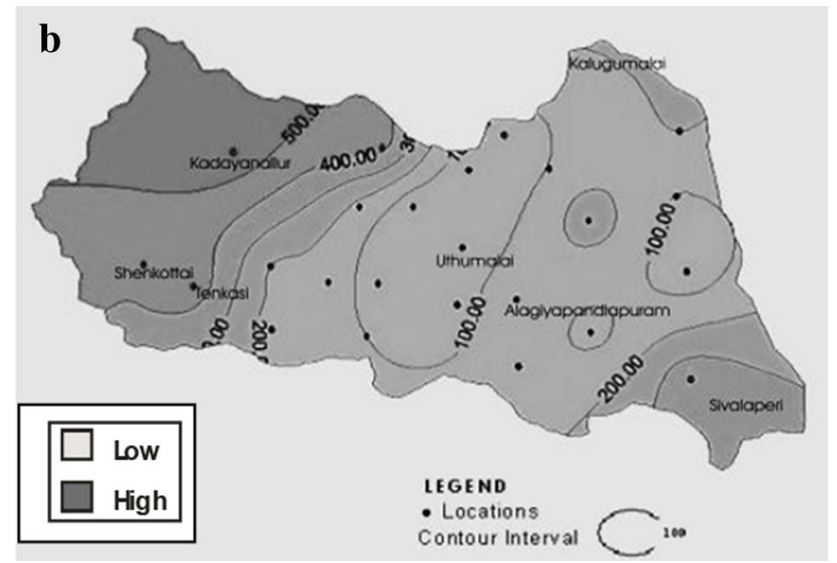

Fig. 5 a Drawdown transmissivity $\left(\mathrm{m}^{2} / \mathrm{d}\right)$, b recovery transmissivity $\left(\mathrm{m}^{2} / \mathrm{d}\right)$ 


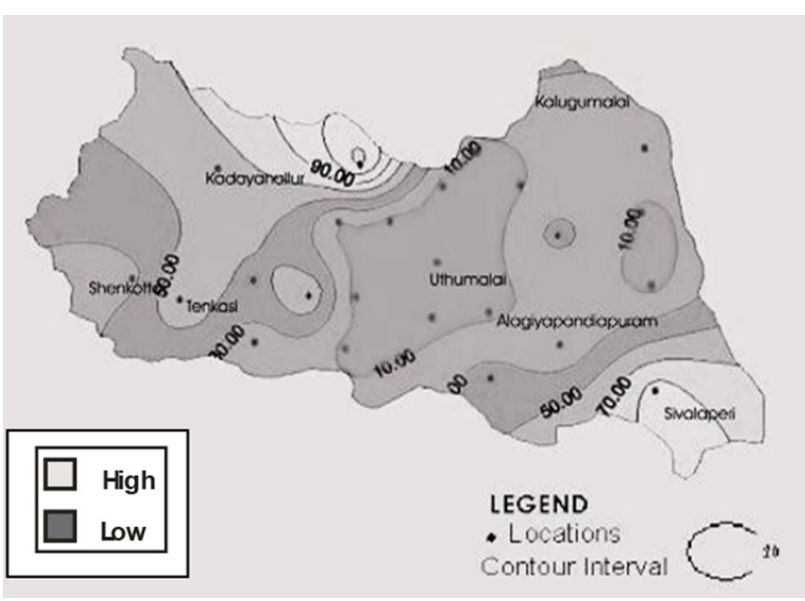

Fig. 6 Optimum yield $\left(\mathrm{m}^{3} / \mathrm{d}\right)$

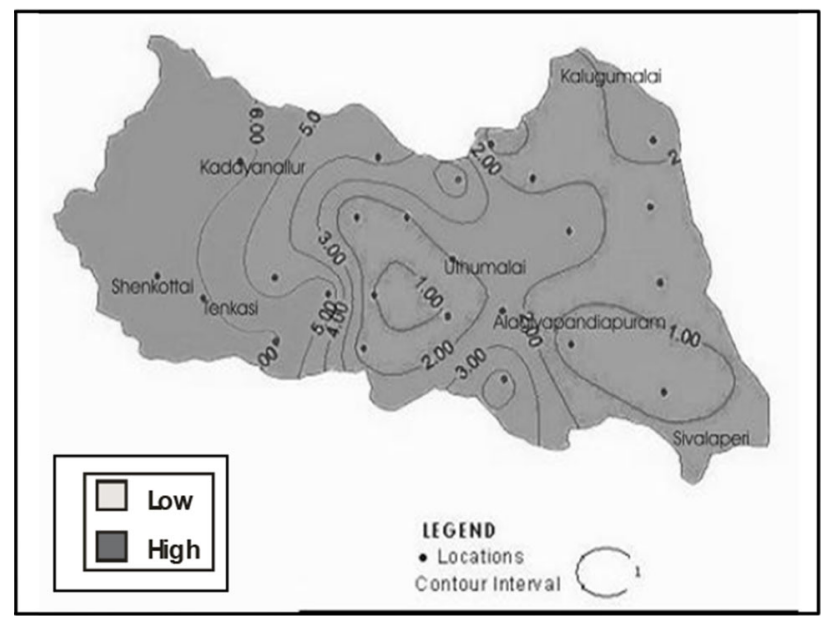

Fig. 7 Saturated thickness (m)

and slow flow of water through the aquifer indicates its anisotropic nature, though the rock type through the study area is homogeneous, and is mainly hornblende biotite gneiss (HBG). The transmissivity in similar HBG complex rocks in different regions is presented in Table 3. The transmissivity range of the HBG complex in the study area is comparatively higher than in the other listed regions.

High values for drawdown and low recovery transmissivity values were observed in areas where the shallow water level was less than $5 \mathrm{~m}$ and where the shallow well depth was less than $10 \mathrm{~m}$. Values of saturated thickness were less than $1 \mathrm{~m}$, and highest specific yield was less than $1001 \mathrm{pm} / \mathrm{mdd} / \mathrm{m}$ in the shallow water level areas. In contrast, when the water level was greater than $5 \mathrm{~m}$ and the well depth exceeded $10 \mathrm{~m}$, low drawdown and high recovery transmissivity were observed. Also, drawdown was low and the recovery transmissivity was high in the charnockite areas rather than in the gneissic areas, whereas drawdown was high and the recovery transmissivity was
Table 3 Comparison of the transmissivity range of the HBG complex in this study area with those in other areas

\begin{tabular}{ll}
\hline Location of the HBG complex & $\begin{array}{l}\text { Transmissivity range } \\
\left(\mathrm{m}^{2} / \text { day }\right)\end{array}$ \\
\hline $\begin{array}{l}\text { Prakasam District, Andhra Pradesh, India } \\
\text { (CGWB 2007) }\end{array}$ & $12.66-150$ \\
$\begin{array}{l}\text { Muvattupuzha river basin, Kerala, India } \\
\text { (Gopinath 2003) }\end{array}$ & $9.22-104.92$ \\
Kano area, Nigeria (Bala et al. 2011) & $16-20$ \\
\hline
\end{tabular}

moderate in the alluvium terrains. The high recovery in charnockite terrains in the western region is because of water seepage from the Western Ghats and geomorphological influences.

\section{Groundwater potential}

The aquifer characteristics play a major role in the identification of groundwater potential zones, because they reflect the rock structures through which the water flows. In general, transmissivity values greater than $100 \mathrm{~m}^{2} /$ day are considered good in hard rock terrains (Sridharan et al. 1995). In this study, the low drawdown, high recovery transmissivity, and high specific capacity represent locations that are considered to delineate the potential groundwater zones for development. The southern and southwestern sides, and a part of northeastern side, had low drawdown values that were less than $50 \mathrm{~m}^{2} /$ day and recovery transmissivity values that were higher than $100 \mathrm{~m}^{2} /$ day (Fig. 5a, b). Sensitivity analysis also showed a similar trend in drawdown transmissivity for most of the locations. The optimum yield was higher, and the aquifer was thicker, in the western part of the study area. Analysis of aquifer parameters indicates that the western and south-central parts of the study area are suitable for groundwater development.

\section{Conclusion}

Aquifer parameters, such as transmissivity, storage coefficient, optimum yield and time required for full recovery, have been analyzed to evaluate the groundwater potential of the study area. Results show that the saturated thickness is high in the western part, where the optimum yield is also high. The recovery transmissivity and specific yield are also relatively high in this area. In contrast, in the central and eastern zones of the study area, the saturated thickness and optimum yields were low. Other aquifer parameters, such as recovery rate, recovery time, and specific yield, also closely reflect the saturated thickness and optimum yield. In certain locations, both the drawdown and recovery were high. 
The high recovery transmissivity and high optimum yield found in the western part, and at some locations in the eastern part, are mainly because of the river course, high secondary porosity, the geomorphological setting and the high weathered thickness. The high drawdown and recovery are because of the lineaments or the structural displacements. The low recovery, saturated thickness and optimum yield may reflect a lack of secondary porosity, compaction of litho units and a shallower weathered layer. Poor groundwater potential is also because of the drilling of deeper bore wells and over-exploitation. However, this attempt at assessing the aquifer parameters of the hard rock terrain has shown the groundwater potential of the area. The evaluation of the aquifer performance test has provided information regarding the construction design of discharge wells and development of groundwater in the study area. Further, computer programs like APE can be used to analyze and understand the aquifer characteristics, such as permeability, transmissivity, and the storage coefficient, and give optimal outcomes to support long-term groundwater exploration and management in hard rock terrains, as in the present study area.

Open Access This article is distributed under the terms of the Creative Commons Attribution License which permits any use, distribution, and reproduction in any medium, provided the original author(s) and the source are credited.

\section{References}

Abdulla NM (1981) Geology of parts of Nanguneri taluk, Tirunelveli District, Tamil Nadu (Un.Pub.report of G.S.I)

Abdulla NN, Paranthaman S (1983) Geology of parts of Tenkasi and Shencottah Taluks, Tirunelveli District, Tamil Nadu (Unpublished Report of G.S.I.)

Aravindan S, Gurunadha Rao VVS, Manivel M, Chandrasekhar SVN (2004) Aquifer parameter studies in the area adjacent to the broken chain of Eastern Ghats, Tamil Nadu. East Ghats EPTRIENVIS Newsl (Quarterly) 10(1):9-11

Balasubramanian A (1986) Hydrogeological investigations of Tambaraparni River Basin, Tamil Nadu, unpublished Ph.D. Thesis, University of Mysore, $\mathrm{p} 349$

Balasubramanian A, Sastri JCV (1989) Techniques of aquifer parameters evaluation using packet computers. In: Gupta CP (ed) Proceedings of the International Workshop on appropriate method, develop and management of groundwater resources in developing countries, vol 2. Oxford \& IBH publishing Co, New Delhi, pp 461-468

CGWB (2007) Groundwater Information, Prakasam District, Andhra Pradesh, Central Groundwater Board, Southern Region, Hyderabad, Report, p 71
Bala AE, Eduvie OM, Byami J (2011) Borehole depth and regolith aquifer hydraulic characteristics of bedrock types in Kano area, Northern Nigeria. Afr J Environ Sci Technol 5(3):228-237

Gopinath G (2003) An integrated hydrogeological study of the Muvattupuzha River Basin, Kerala, India, Unpublished Ph.D thesis submitted to the Cochin University of Science and Technology, Cochin, Kerala, pp 271

Jain JK (1977) Under groundwater resources of India. Trans R Soc London B 278:504-507

Limaye DG (1973) Discussion on studies of specific capacity of wells in hard rocks and alluvial formations of Mysore State. In: Krupanidhi et al (eds) Proceedings of the International Symposium on Groundwater resources, vol IV. Madras, India, p 2-87

Mahajan G (1995) Groundwater surveys and investigation. Ashish Publishing House, New Delhi, p 543

Patel AS (2004) Water resources management and peoples participation. J Appl Hydrol XVII(4):1-7

McElwee CD (1980a) Theis parameter evaluation from pumping tests by sensitivity analysis. Groundwater 18(1):56-60

McElwee CD (1980b) The Theis equation; evaluation, sensitivity to storage and transmissivity, and automated fit of pump test data. Kans Geol Surv Groundw 3:39

McQueen IS (1973) Evaluating the reliability of specific yield determinations. J Res US Geol Surv 1:371-376

Narasimhan TN (1965) On testing open wells. Indian Geohydrol I:101-105

Prodanoff JHA, Mansur WJ, Mascarenhas FCB (2006) Numerical evaluation of Theis and Hantush-Jacob well functions. J Hydrol 318:173-183

Kumar R, Singh RD, Sharma KD (2005) Water resources of India. Curr Sci 89(5):794-811

Ramakrishnan S (1998) Ground water, Chennai, p 761

Ram Mohan HS (1984) A climatological assessment of the water resources of Tamil Nadu. Indian J Power River Val Dev, pp 58-63

Rasmussen WC (1964) Permeability and storage of heterogeneous aquifers in the United States. Int Assoc Sci Hydrol Publ 64:317-325

Singhal DC (1984) An integrated approach for groundwater investigation in hardrock areas-a case study. In: International workshop on rural hydrogeology and hydraulics in fissured basement area. Roorkee, pp 87-93

Singhal BBS, Gupta RP (1999) Applied Hydrogeology of fractured rocks. Kluwer Academic Publishers, The Netherlands

Slichter CS (1906) The under flow in Arkansas valley in Western Kansas, U.S.G.S, water supply paper, 153, p 61

Sridharan K, Mohan Kumar MS, Sekhar M (1995) Groundwater flow and storage in hard rocks aquifers. In: Proceedings of workshop on artificial recharge of groundwater in granite terrain, CGWB, pp 86-107

Summers WK (1972) Specific capacities of wells in crystalline rocks. Groundwater 10(6):37-47

Theis CV (1935) The relation between the lowering of the piezometric surface and the rate and duration of discharge of a well using groundwater storage. Trans Am Geophys Union 16:519-524

Todd TK (1980) Groundwater hydrology. Wiley, New York

Walton WC (1970) Groundwater resource evaluation. McGraw Hill Book Co., New York, p 664 